\title{
EDGE INFLUENCE OVER FUNCTIONAL TREE TRAITS IN AN ATLANTIC FOREST REMNANT
}

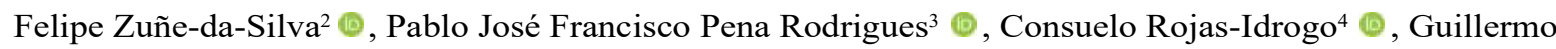

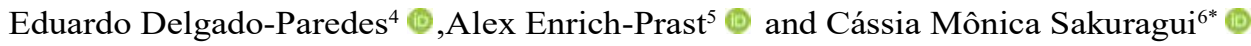

\footnotetext{
${ }^{1}$ Received on 21.07.2021 accepted for publication on 27.10.2021.

${ }^{2}$ Universidade Federal do Rio de Janeiro, Mestre em Botânica, Rio de Janeiro, RJ - Brasil. E-mail: <lfelipezd15@hotmail.com>.

${ }^{3}$ Instituto de Pesquisas Jardim Botânico do Rio de Janeiro, Rio de Janeiro, RJ - Brasil. E-mail: <pablojfpr@hotmail.com>.

${ }^{4}$ Universidad Nacional Pedro Ruiz Gallo, Facultad de Ciencias Biologicas , Lambayeque, Peru. E-mail: <crojas@unprg.edu.pe>and <guidelg2015@yahoo.es>.

${ }^{5}$ Universidade de Linköping, Departamento de Estudos Temáticos, Linköping, Suécia. E-mail: <aenrichprast@gmail.com>.

${ }^{6}$ Universidade Federal do Rio de Janeiro, Instituto de Biologia, Rio de Janeiro, RJ - Brasil. E-mail: <cmsakura12@gmail.com>.

*Corresponding author.
}

\begin{abstract}
Habitat fragmentation is one of the leading causes of edge genesis and its effects. Functional tree traits such as wood density, height, and diameter are essential variables from which it is possible to infer several ecological processes. This study assessed the variability of the functional traits of trees over two habitats (edge and interior) of a forest remnant. The hypothesis tested were i) the functional traits would have lower values at the edges than the interior, and ii) environmental variables would influence such differences. This study was carried out in the largest Atlantic Forest remnant within Serra da Tiririca State Park, Brazil, by establishing ten plots $(50 \times 20 \mathrm{~m})$ among different habitats. Within each plot, wood samples were taken from all trees with a diameter of $\geq 10 \mathrm{~cm}$. It was recorded the altitude, distance from the plots to the edge, and fire records as possible explanatory variables (environmental variables). Wood density was obtained using the immersion method. To verify differences in functional traits by habitat, the Wilcoxon test was applied. Additionally, the influence of explanatory variables on functional traits through generalized linear models was evaluated. One hundred eighty-five trees were recorded at the edges and 218 trees at the interior of the remnant. Wood density and tree height were significantly lower in the edges than in the interior. Furthermore, the best models indicated significant relationships between wood density and habitats, as well as diameter and distance to the edge. This study was effective in raising suitable variables to predict edge effects.
\end{abstract}

Keywords: Wood density; Tropical rainforest; Habitat fragmentation.

\section{INFLUÊNCIA DAS BORDAS SOBRE CARACTERÍSTICAS FUNCIONAIS DAS ARVORES EM UM REMANESCENTE DE MATA ATLÂNTICA}

RESUMO - A fragmentação de habitats é uma das principais causas da criação de bordas e seus efeitos. Características funcionais das árvores, como a densidade da madeira, altura e diâmetro, são variáveis essenciais que permitem inferir vários processos ecológicos. Este estudo avaliou a variabilidade das características funcionais das árvores em dois tipos de habitats (borda e interior) de um remanescente florestal. Foram testadas as hipóteses de que i) as características funcionais teriam menores valores nas bordas do que no interior, e que ii) as variáveis ambientais influenciam essas diferenças. Este estudo foi realizado no maior remanescente de Mata Atlantica dentro do Parque Estadual da Serra da Tiririca, Brasil, estabelecendo dez parcelas (50 $\times 20 \mathrm{~m}$ ) entre diferentes habitats. Dentro de cada parcela foram retiradas amostras de madeira de todas as árvores com diâmetro $\geq 10 \mathrm{~cm}$. Além disso, foram registradas a altitude, distância das parcelas até a borda e registros de queimadas como possiveis variáveis explicativas (variáveis ambientais). A densidade da madeira foi obtida através do método de imersão. Para verificar diferenças nas características funcionais por tipo de habitat, foi aplicado o teste de Wilcoxon. Adicionalmente, foi avaliada a influência das variáveis explicativas sobre as características funcionais por meio de modelos lineares generalizados. Cento e oitenta e cinco árvores foram registradas nas bordas e 218 árvores no interior do remanescente. A densidade da madeira e a altura das árvores foram significativamente menores nas bordas do que no interior. Além disso, os melhores modelos

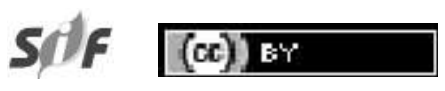

Revista Árvore 2022;46:e4603 http://dx.doi.org/10.1590/1806-908820220000003 
indicaram relações significativas entre densidade da madeira e o tipo de habitat; assim como, entre o diametro e distância até a borda. Este estudo foi eficaz em abordar variáveis adequadas para prever os efeitos de borda no remanescente.

Palavras-Chave: Densidade da madeira; Floresta tropical; Fragmentação de habitat.

\section{INTRODUCTION}

Forest edges play an essential role in the ecosystem balance, receiving more recently, particular attention in ecological studies (Murcia, 1995; Laurance et al., 2007; Magnago et al., 2017). Edges or transition zones originate mainly because of habitat fragmentation (Laurance et al., 2002), which causes isolation from the forest matrix (remnants), reduces local biodiversity, and changes the microclimate conditions that affect the edge populations on the remnants (edge effect) (Laurance et al., 2018). Among the main changes associated with the edge effect, high solar radiation, high temperature, low humidity, and strong winds stand out (Laurance and Curran, 2008; Laurance et al., 2011; Magnago et al., 2015). However, edges are dynamic in space and time and can also be induced by numerous biotic and abiotic factors (Laurance et al., 2018).

Many conditions that affect forest edges occasionally influence the composition of tree species (Laurance et al., 2002; Laurance et al., 2007; Laurance et al., 2011), such the topography (Gehlhausen et al., 2000), the population density of shrub-tree vegetation (Wright et al., 2010) and vulnerability to fires (Cochrane and Laurance, 2002). Such parameters directly depend on the variability of functional traits, such as wood density, tree diameter, and height (Laurance et al., 2006a), whose magnitude is strongly related to trees growth and biomass (Chave et al., 2014).

Variation in functional traits is usually related to climate change and resilience towards changes (Poorter et al., 2010; Gratani, 2014; Falster et al., 2018). In this sense, edge trees are often reported presenting low wood density, smaller diameters, and shorter heights compared to individuals from the interior of the forest remnant (Oliveira-Filho et al., 1997; Magnago et al., 2014; Rodrigues et al., 2016; Berenguer et al., 2018). However, some studies suggested that they do not significantly differ in functional traits concerning habitat types (Pires et al., 2014; Magnago et al., 2014; Couto-Santos et al., 2021). In context, functional traits can make it possible to infer successional ecological processes (Chazdon et al., 2010). Tree communities studied in Brazilian biomes reinforce the importance of wood density in the forest structure (e.g.: Baker et al., 2004; Berenguer et al., 2018; Zimermann et al., 2019). However, due to the severe lack of data, the usefulness of wood density is scarcely explored as a predictive tool for succession stages (Padilha and Marco-Junior, 2018). On the other hand, the variation in trees diameter and height have been widely explored in forestry studies (Feldpausch et al., 2011), mainly studies on restoration process (Salomão et al., 2014), phytosociology (Turchetto et al., 2017), and habitat fragmentation (Haddad et al., 2015).

The Atlantic Forest is one of the most currently threatened neotropical biomes of rainforests, being regarded as one of the five most important biodiversity hotspots in the biosphere (Myers et al., 2000), with only $12.4 \%$ of its original coverage remaining (SOS Mata Atlântica and INPE, 2019). Most forest reduction is attributed to habitat fragmentation caused by anthropogenic disturbances (Rezende et al., 2018). Although there is continuous devastation of this biome, studies in small remnants indicate high rates of species heterogeneity (e.g.: Rocha and Amorim, 2012; Eisenlohr and Oliveira-Filho, 2015; Pontes et al., 2019). In this sense, edge studies usually aim at assessing functional diversity (Tabarelli et al., 2010; Magnago et al., 2014; Couto-Santos et al., 2021). When exploring the functional traits of trees, they are continuously oriented to studies in small remnants (Nascimento and Laurance, 2006; Santos et al., 2008; Santo-Silva et al., 2016), with particular species (Costa et al., 2020), and in specific environmental gradients (Rodrigues et al., 2016).

However, evaluating the edges in the light of the functional traits could have a high explanatory content of their effects (Magnago et al., 2014) since changes in the performance of the functional traits affect the growth, reproduction, and survival of individuals

Revista Árvore 2022;46:e4603 
(Violle et al., 2007). In this sense, this study aimed to assess the variability in tree functional traits over two habitat (edge and interior) in a forest remnant in Brazil. The hypothesis tested were i) traits as wood density, height, and tree diameter have lower values at the edges than in the interior, and ii) environmental variables influence such differences.

\section{MATERIAL AND METHODS}

\subsection{Study area}

This study was carried out within Serra da Tiririca area, the largest forest remnant in the Serra da Tiririca State Park (PESET), located between the municipalities of Niterói and Maricá, in the State

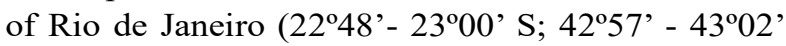
W) (Figure 1). PESET comprises 3492 ha, and the studied sector shows 1975 ha, distributed among the continental section (1789 ha) and marine limits (187 ha). PESET is inserted in the Atlantic Forest biome, with its flora representing the formation of dense submontane rainforest, with portions of rocky outcrops (Barros, 2008). The climate of the region is humid and warm, with heavy rains in the summer and dry season in the winter (Köppen's Aw) (Alvares et al., 2013), with an annual average temperature of $23.7^{\circ} \mathrm{C}$, an average of the total annual precipitation $~$ $1172 \mathrm{~mm}$, annual relative humidity of $\sim 80 \%$ and, the edaphic constitution is formed mainly by Agrisoils, Gleissosoils, Neossoils, Cambisoils, and Litossoils (INEA, 2015).

The use and occupation of the PESET occurred from the first prehistoric nomadic groups (Kneip, 1995) through the occupation by the Tupi indigenous people until the arrival of the Portuguese colonizers (Barros, 2008). In the colonial era, the intense Portuguese trade on the Brazilian wood Paubrasilia echinata (Lam.) Gagnon, H.C. Lima \& G.P. Lewis and other large trees transformed the natural landscape into devastated areas (Barros, 2008). Between the 16th and 17th centuries, sesmarias, extractive activities, and the establishment of sugar cane mills were primarily responsible for the devastation of vast extensions of native forests in the Atlantic Forest (Barros, 2008). With the decline of monocultures between the 19th and 20th centuries, natural areas managed to recover their native vegetation, but not for a long time (Barros, 2008). From the mid-20th century until today, large subdivisions and real estate growth dictate the dynamics and transformation of landscapes (Vallejo, 2005). On November the 29th, 1991, State Law No. 1,901 (Rio de Janeiro, 1991) determined the creation and control of the PESET.

\subsection{Sample collection and data analyses}

Ten plots of $50 \times 20 \mathrm{~m}$ ( 1 ha) were unsystematically established between November 2019 and December 2020. Five plots no more distant than $20 \mathrm{~m}$ from an anthropogenic edge and five inside the remnant (plots average nearest to edge $=175 \mathrm{~m}$ ) were set, all with a minimum distance of $200 \mathrm{~m}$ from each other (Figure 1).

In each plot, woody trees were sampled following the protocol proposed by Chave (2006); where, crosssections of the xylem were taken with a Pressler probe (Haglöf Sweden ${ }^{\circledR}, 500 \mathrm{~mm}$, Sweden) in the transversal direction of the trunk and at breast height. Also, each height (estimated from the length of high pruning poles) and diameter at breast height (DBH) of all trees $\geq 10 \mathrm{~cm}$ were recorded. In addition, environmental data (altitude, the closest distance between the edge of each plot, and the edge of the forest in a straight line) and the occurrence of fires were measured. The woody samples were dried in an oven at $105 \pm 2{ }^{\circ} \mathrm{C}$ and weighed on an analytical precision scale (Marte Cientifica $^{\odot}$, AD330, Brazil). The immersion method (ABNT, 2003) was used to estimate the density of wood samples, using Equation 1:

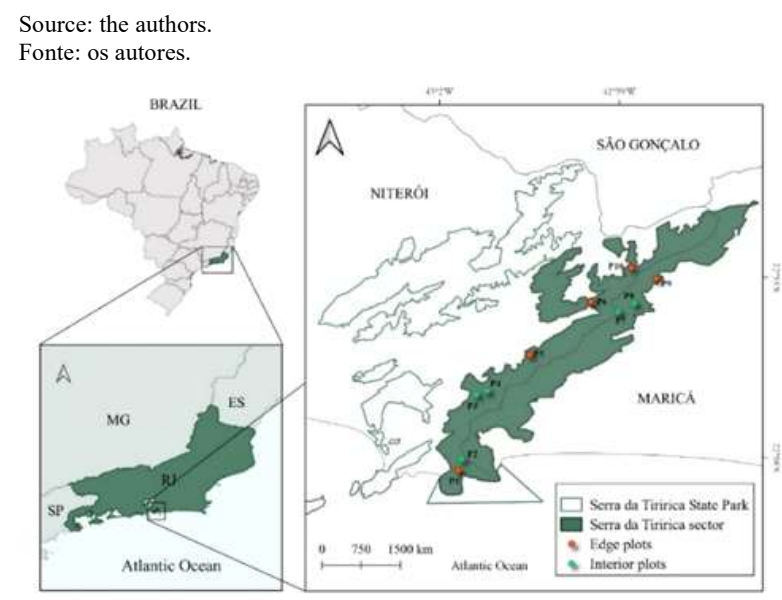

Figure 1 - Map and location of the study area, showing the plots (P) studied in Serra da Tiririca, Serra da Tiririca State Park, between 2019 and 2020.

Figura 1 - Mapa e localização da área de estudo, mostrando as parcelas $(P)$ estudadas na Serra da Tiririca, Parque Estadual da Serra da Tiririca, entre 2019 e 2020. 
$p=\frac{m}{m d i f f}$

Eq. 1

where $\rho=$ wood density $\left(\mathrm{g} . \mathrm{cm}^{-3}\right) ; m=$ dry weight of the wood $(\mathrm{g})$; mdiff $=$ weight difference of the submerged wood (g), which corresponds to its volume $\left(\mathrm{cm}^{3}\right)$. The woody samples were deposited in the Herbário Museu Nacional (R).

Fire occurrence data were extracted from the database of the Queimadas Program - INPE (https:// queimadas.dgi.inpe.br/queimadas/portal), filtering records of outbreaks between January 2010 and May 2021 , in a limit distance of $5 \mathrm{~km}$ around the study site. The fire information applied in this study refers to the attribute fire risk - a meteorological estimate correlated to days without rain in a given location, type of vegetation, maximum temperature, minimum relative humidity, topography, latitude, and presence of local fire (INPE, 2021). The fire risk was evaluated based on the average of fires in a circular area of 100 $\mathrm{m}$ in radius from each plot. When no fire records were found within the perimeter, the average between the two closest to the plot was considered.

\subsection{Statistical analysis}

To test the normality of the response variables (wood density, height, and tree diameter), the ShapiroWilk test was used. When the assumption was not met, logarithmic and root-quadratic transformations were performed. If the variables did not meet the tests' assumptions even after transformations, they were treated using non-parametric tests, according to their initial distribution. For all statistical analyzes, a significance level of $\mathrm{p}<0.05$ was adopted. All statistical analyzes were generated in the $\mathrm{R}$ 4.1.1 statistical environment (R Core Team, 2021).

To assess whether the median wood density, diameter, and height of trees individuals showed significant differences between the edges and the interior of Serra da Tiririca, the non-parametric Wilcoxon test was applied. Additionally, the initial relationship between the three response variables was verified using Pearson's correlation coefficient. Also, the trees were separated by diameter and height classes and compared between edge and interior using the Wilcoxon test. Finally, to assess the influence of the explanatory variables (distance from plots to edge, altitude, fire risk, habitat type, and interactions) on the median per plot of the response variables, generalized linear models (GLM) were used. The distance-to-edge variable was log-transformed to reduce heteroscedasticity and increase the probability

Source: the authors Fonte: os autores.

A

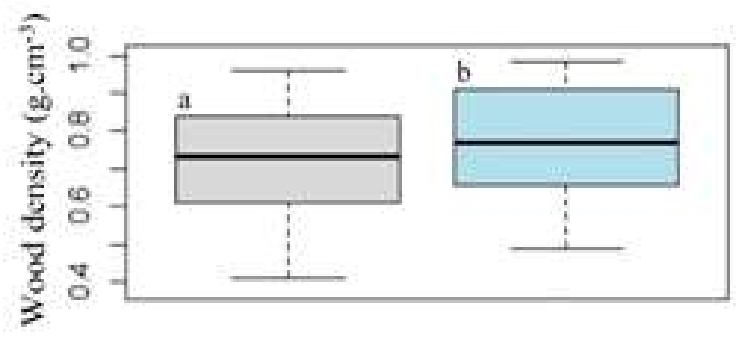

B

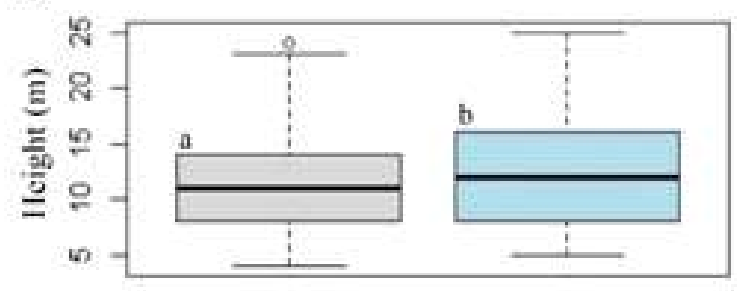

C

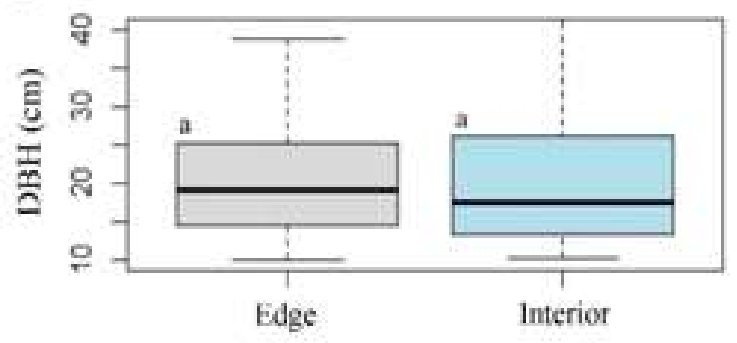

Figure 2 - Boxplots showing the variability of the wood density at the edge and the interior of remnant (A), height (B), and diameter at breast height (DBH) (C) of the tree individuals in the Serra da Tiririca, between 2019 and 2020. The line between the boxes represents the median, the limits of the boxes cover the 1 st and 3 rd quartiles, and dashes, the whole data. Different lowercase letters above the boxes indicate significant differences $(\mathrm{p}<0.05)$.

Figura 2 - Diagrama de caixas mostrando a variabilidade da densidade da madeira nas bordas e no interior da floresta (A), altura $(B)$ e diâmetro à altura do peito (DAP) (C) dos individuos na Serra da Tiririca, entre 2019 e 2020. A linha entre as caixas representa a mediana, os limites das caixas cobrem o $1^{\circ}$ e $3^{\circ}$ quartis, e os traços, todos os dados. Diferentes letras minúsculas acima das caixas indicam diferenças significativas $(p<0,05)$. 
of standard distribution. For selecting the best GLMs, the best explanatory variables for each model were found through the dropterm function of the MASS package (Ripley et al., 2013). To assess the goodness of fit of the models, the explanatory variables were submitted to an analysis of variance with an $\mathrm{F}$ test and the measures of discrepancies were verified through deviance. Finally, models with the lowest values were selected, according to the Akaike Information Criterion (AIC) (Burnham et al., 2011), and the (adjusted) amount of deviance counted for each model was calculated from the Dsquared $\left(\mathrm{D}^{2}\right)$ function of the modEvA package (Barbosa et al., 2013). This function, known as pseudo- $\mathrm{R}^{2}$ (or $\mathrm{R}^{2}$ analog for GLM), calculates the variation ratio of each model (Guisan and Zimmermann, 2000). For all GLMs, Gaussian distribution with identity link was used.

\section{RESULTS}

In a total of 403 trees recorded, 185 were on the edges and 218 in the interior. Wood density and tree height showed significant differences between habitats (edge vs. interior). The median wood density was significantly lower $(z=16261 ; p<0.001)$ at the edges $\left(0.73 \pm 0.14{\left.\mathrm{~g} . \mathrm{cm}^{-3}\right)}^{-}\right.$when compared to the interior $\left(0.77 \pm 0.14{\mathrm{~g} . \mathrm{cm}^{-3}}^{-}\right)$. Likewise, the median height of the individuals was lower at the edge $(11 \mathrm{~m})$ than in the interior $(12 \mathrm{~m})(\mathrm{z}=17120 ; \mathrm{p}<0.05)$. In contrast, the diameter was not significantly different, with a median of $19.10 \mathrm{~cm}$ at the edges and $17.51 \mathrm{~cm}$ at the interior $(z=21124 ; p=0.41)$ (Figure 2). Pearson's test showed that none of the variables showed significant correlations between them $(\mathrm{p}>0.05)$.

The diameter classes followed a positive asymmetric distribution, showing significance between the edge and interior of the forest only for the tree classes between 10-20 cm ( $\mathrm{z}=8671 ; \mathrm{p}<0.0001)$. In contrast, height classes showed a symmetrical distribution trend but no significance in their classes (Figure 3).

The best GLMs for wood density, height, and tree diameter showed low coefficients of the uncertainties of the estimates about the explanatory variables (distance from the plots to the edges, altitude, fire risk, and habitat type) (Table 1). There was a significant difference between wood density and habitat type (Table 1) and a strong relationship in this model ( $\mathrm{D}^{2}$ $=0.71)$. Likewise, significant differences were found between median DBH and distance of plots to edge (Table 1) and a strong relationship in this model $\left(\mathrm{D}^{2}\right.$ $=0.63)$.

\section{DISCUSSION}

Variability on tree functional traits often allows us to understand how individuals interact in different ecological gradients (Violle et al., 2007). This paper aimed to assess the variability in functional traits of trees over two habitats (edge and interior) in an Atlantic Forest remnant. In this sense, significant

Source: the authors

Fonte: os autores.

A

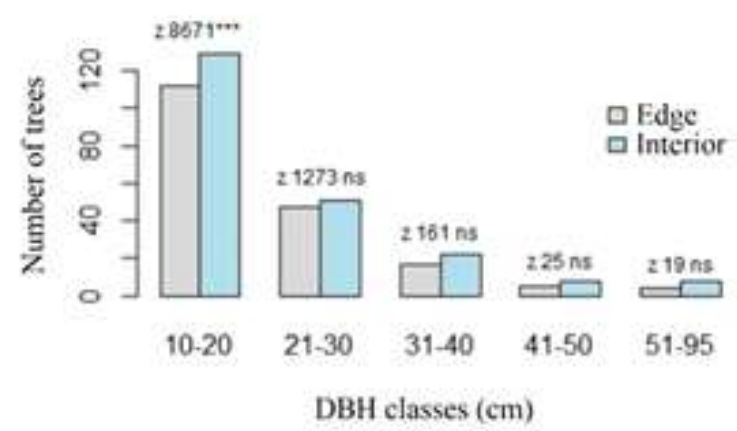

B

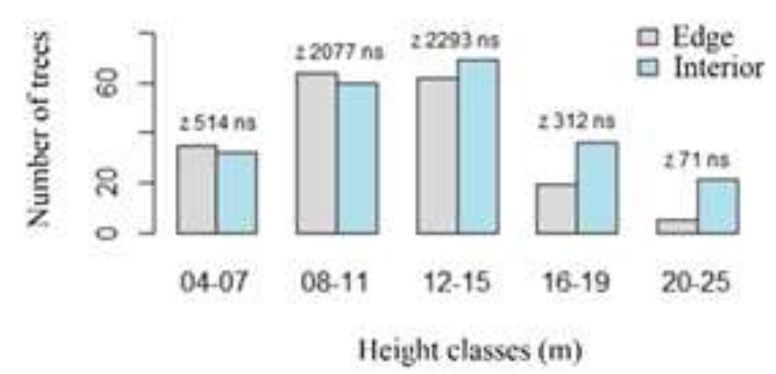

Figure 3 - Number of trees per class of diameter $(\mathrm{A})$ and height $(\mathrm{B})$, comparing the edges and the interior of Serra da Tiririca, between 2019 and $2020 . \mathrm{DBH}=$ diameter at the breast height. $\mathrm{p}<0.0001^{\prime} * * * ; ; \mathrm{ns}=$ non-significant.

Figura 3 - Número de árvores por classes de diâmetro (A) e altura (B), comparando as bordas e o interior da Serra da Tiririca, entre 2019 e 2020. DAP = diâmetro a altura do peito. $p<0,0001^{\text {' } * * * ' ; ~} n s=$ não significativo. 
Table 1 - Generalized linear models generated by the relationships between wood density, height, and diameter versus explanatory variables and their interactions.

Tabela 1 - Modelos lineares generalizados gerados pelas relações entre densidade da madeira, altura e diâmetro versus variáveis explicativas e suas interações.

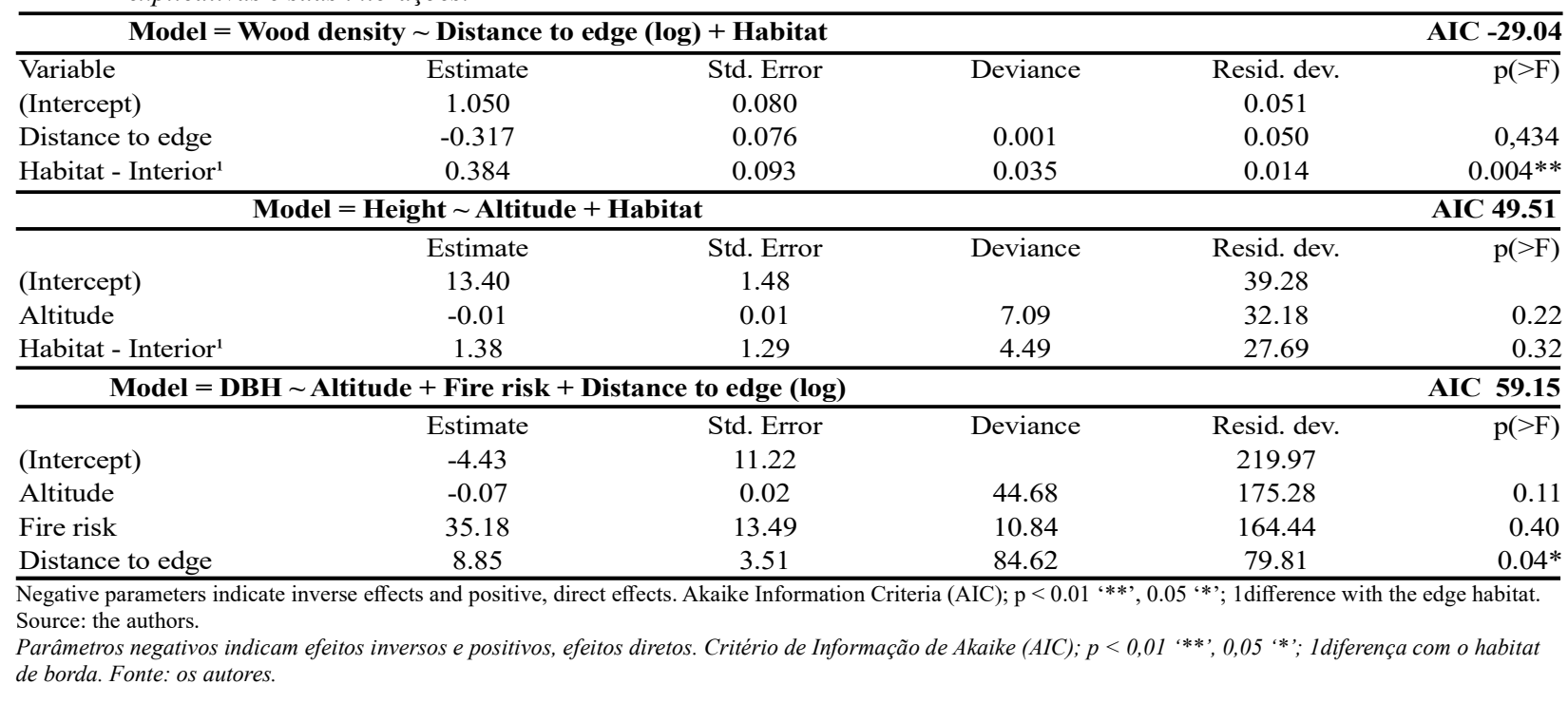

differences were observed in functional traits (wood density and tree height) related to habitat type. These traits showed lower values for the edges compared to the interior. Furthermore, it was found that the environmental variables influenced the variation of the functional traits (wood density and tree diameter), which are fundamental to explaining the trees individuals' ecological role.

Wood density is a property that is vulnerable to environmental changes due to its relationship with the mass and volume of trees (Chave et al., 2006). Wood density can vary according to habitat type, presenting lower values in anthropic forests and edges when compared to undisturbed forests and the interior (Muller-Landau, 2004; Laurance et al., 2006b; Berenguer et al., 2018). However, few authors reported that wood density has no variation to the edges and interior of the remnants (Magnago et al., 2014, Santo-Silva et al., 2016; Dreyer et al., 2020). Significant differences were found in wood density compared to habitat type in the present study, with lower values for edges than for the interior. In this context, divergences between studies could indicate the lack of patterns in this functional trait. Potential explanations are the local range limitation of the wood density (Atlantic Forest, $0.6-0.8$ g.cm ${ }^{-3}$ ) (Padilha and Marco-Junior, 2018) and their phylogenetic evolution
(Chave et al., 2006). In perspective, the variation in wood density is mainly related to the type of soil and water regimes (Rüger et al., 2012), where trees with lower wood densities retain more water (Borchert, 1994). However, this is not relevant in Serra da Tiririca because it is a rainforest where the average monthly rainfall exceeds $95 \mathrm{~mm}$ (INEA, 2015). In contrast, variability could also be associated with regional historical-ecological events (Poorter et al., 2019), influenced by the succession of individuals in different habitat types. In this sense, the wood density of Serra da Tiririca - which presents an average close to the average of Atlantic Forest species (0.70 g.cm ${ }^{-3}$ ) (Chave et al., 2009) - would be influenced by recognized events, as the intense extraction of charcoal between the 18th and 20th centuries (Oliveira et al., 2020), as well as by the local floristic heterogeneity (Barros, 2008).

Dendrometric traits are essential to assess the forest structure. The height and diameter of trees also vary according to the habitat types (Nascimento and Laurance, 2006). In this study, significant differences in the tree heights across habitat types were detected. Taller trees, as expected, occurred inside the remnant than at the edges. Potential causes for this pattern are the high mortality rate of trees at the edges, caused mainly by the direct interaction with the edge effects,

Revista Árvore 2022;46:e4603 
such as winds and fires (Cochrane and Laurance, 2002; Poorter et al., 2010; Laurance and Curran, 2008).

In contrast, no significant differences were found in the median tree diameter compared between habitats, but significant differences in the diametric classes were recorded. Edges showed fewer trees between 10 to $20 \mathrm{~cm}$ when compared to the interior. In this context, it is worth pointing out that this pattern might be related to forest succession. Serra da Tiririca is a secondary forest, where the edge conditions favor the establishment and growth of pioneer and secondary species (Laurance et al., 2006b; Nascimento and Laurance, 2006; Chazdon et al., 2010).

The best models indicate the relationship of the plots to edges as the direct influence of wood density and tree diameter. These response variables are good predictors of the edge effect, which can exceed 300 $\mathrm{m}$ of distance from the edge to the interior (Laurance et al., 2002), varying the intensity of the parameter according to the size of the remnant (Nascimento and Laurance, 2006; Laurance et al., 2006a, b; Laurance et al., 2018). None of the functional traits were significantly related to the fire risk. However, adding the fire risk to the model allowed the significant relationship between diameter and distance from the edges. In this context, other unmeasured variable responses could be associated with fire risk with the edges because edges are highly vulnerable to fires and are strongly related to the frequent juxtaposed to pastures and frequent anthropogenic fires (Cochrane and Laurance, 2002).

\section{CONCLUSIONS}

There are significant differences in the functional traits between trees individuals in comparing the edge and interior of the remnant. Wood density and height showed lower values at the edges, while the diameter was not different. Wood density and diameter were the functional traits most related to habitat type and the distance to the edge, respectively, being good predictors of the edge effect. In contrast, there was no relationship between height and explanatory variables.

Here, the variability of functional traits tells us how essential studies on forest edges are for a complete understanding of their effects. Furthermore, it is vital to continue studies on the plots installed in Serra da Tiririca to follow the dynamic of individuals in space-time on habitat types. Finally, we recommend using our findings to assist the park's management in conserving the forest remnant.

\section{AUTHOR CONTRIBUTIONS}

This study was part of the master dissertation of the first author. Felipe Zuñe-da-Silva: Conceived and designed the study, data collection, data analysis, and text written; Pablo José Francisco Pena Rodrigues, Consuelo Rojas-Idrogo and Guillermo Eduardo Delgado-Paredes: technical review and text review; Alex Enrich-Prast and Cassia Mônica Sakuragui: research supervision, technical review, and text review. All authors approved the final version of the manuscript.

\section{ACKNOWLEDGMENT}

We wish thank to the Coordenação de Aperfeiçoamento de Pessoal de Nível Superior Brasil (CAPES) for providing the first author with a scholarship (Grant No. 88887.500463/2020-00). We are grateful to André Costa, Erbersson Conceição, Rafael Fonseca and Angêlo Coutinho for the valuable field assistance, and PESET/INEA for research authorizations. The authors give a special thanks to Dra. Vera Huszar and Dra. Andrea Costa for the suggestions and first revision of the manuscript, and we also wish to extend our thanks to Dra. Bárbara de Sá Haiad for facilitating access to the Departamento de Botânica - Museu Nacional/UFRJ and Dr. Nilber da Silva for receiving the wood samples in the Herbário Museu Nacional (R).

\section{REFERENCES}

Associação Brasileira de Normas Técnicas - ABNT. NBR 11941: Madeira: determinação da densidade básica. Rio de Janeiro; 2003.

Alvares CA, Stape JL, Sentelhas PC, Gonçalves JLM, Sparovek G. Köppen's climate classification map for Brazil. Meteorologische Zeitschrift. 2013;2(6):711-728. doi: 10.1127/09412948/2013/0507

Baker TR, Phillips OL, Malhi Y, Almeida S, Arroyo L, Di Fiore A, et al. Variation in wood density determines spatial patterns in Amazonian forest biomass. Global Change Biology. 2004;10(5):545- 
562. doi: 10.1111/j.1365-2486.2004.00751.x

Barbosa MA, Real R, Muñoz AR, Brown JA. New measures for assessing model equilibrium and prediction mismatch in species distribution models. Diversity and Distributions. 2013;19(10):1333-1338. doi: $10.1111 /$ ddi. 12100

Barros AAM. Análise florística e estrutural do Parque Estadual da Serra da Tiririca, Niterói e Maricá, RJ, Brasil [thesis]. Rio de Janeiro: Escola Nacional de Botânica Tropical, Instituto de Pesquisas Jardim Botânico do Rio de Janeiro; 2008.

Berenguer E, Gardner TA, Ferreira J, Aragão LE, Mac Nally R, Thomson JR, et al. Seeing the woods through the saplings: Using wood density to assess the recovery of human-modified Amazonian forests. Journal of Ecology. 2018;106(6):2190-2203. doi: $10.1111 / 1365-2745.12991$

Borchert R. Soil and stem water storage determine phenology and distribution of tropical dry forest trees. Ecology. 1994;75(5):1437-1449. doi: $10.2307 / 1937467$

Burnham KP, Anderson DR, Huyvaert KP. AIC model selection and multimodel inference in behavioral ecology: some background, observations, and comparisons. Behavioral ecology and sociobiology. 2011;65(1):23-35. doi: 10.1007/ s00265-010-1029-6

Chave J. Measuring wood density for tropical forest trees: A field manual. Toulouse: Université Paul Sabatier, Pan-Amazonia Project; 2006.

Chave J, Muller-Landau HC, Baker TR, Easdale TA, Steege HT, Webb CO. Regional and phylogenetic variation of wood density across 2456 neotropical tree species. Ecological Applications. 2006;16(6):2356-2367. doi:10.1890/10510761(2006)016[2356:RAPVOW] 2.0.CO;2

Chave J, Coomes D, Jansen S, Lewis SL, Swenson NG, Zanne AE. Towards a worldwide wood economics spectrum. Ecology Letters. 2009;12(4):351-366. doi: 10.1111/j.14610248.2009.01285.x

Chave J, Réjou-Méchain M, Búrquez A, Chidumayo E, Colgan M, Delitti W, et al. Improved allometric models to estimate the aboveground biomass of tropical trees. Global change biology. 2014;20(10):3177-3190. doi: 10.1111/gcb.1262

Chazdon RL, Finegan B, Capers RS, Salgado-Negret B, Casanoves F, Boukili V, et al. Composition and dynamics of functional groups of trees during tropical forest succession in northeastern Costa Rica. Biotropica. 2010;42(1):31-40. doi: 10.1111/j.174474 29.2009.00566.x

Cochrane MA, Laurance WF. Fire as a largescale edge effect in Amazonian forests. Journal of Tropical Ecology. 2002;18(3):311-325. doi: 10.1017/ S0266467402002237

Costa WS, Cunha M, Rodrigues PJFP, Iguatemy MA, Valladares F, Barros CF. Intraspecific variation in functional wood anatomy of tropical trees caused by effects of forest edge. Forest Ecology and Management. 2020;473:118305. doi: 10.1016/j. foreco.2020.118305

Couto-Santos APL, Miranda LDP, Rossado DR. Functional diversity of plant communities at edge and interior of a submontane Atlantic Forest: greater functional than compositional stability. Rodriguésia. 2021;72:e00352019. doi: 10.1590/2175-

7860202172022

Dreyer JBB, Schlickmann MB, Cuchi T, Vieira FS, Moraes GC, Higuchi P, et al. Estruturação espacial de traços funcionais de espécies arbóreas em função da distância da borda em Floresta Alto-Montana no sul do Brasil. Ciência Florestal. 2020;30(3):743-754. doi: $10.5902 / 1980509833586$

Eisenlohr PV, Oliveira-Filho AT. Revisiting patterns of tree species composition and their driving forces in the Atlantic Forests of Southeastern Brazil. Biotropica. 2015;47(6):689-701. doi: 10.1111/ btp. 12254

Falster DS, Duursma RA, FitzJohn RG. How functional traits influence plant growth and shade tolerance across the life cycle. Proceedings of the National Academy of Sciences.

2018:115(29):E6789-E6798. doi: 10.1073/ pnas. 1714044115

Feldpausch TR, Banin L, Phillips OL, Baker TR, Lewis SL, Quesada CA, et al. Height-diameter allometry of tropical forest trees. Biogeosciences. 2011;8(5):1081-1106. doi: 10.5194/bg-8-1081-2011

Revista Árvore 2022;46:e4603 
Gehlhausen SM, Schwartz MW, Augspurger CK. Vegetation and microclimatic edge effects in two mixed-mesophytic forest fragments. Plant Ecology. 2000;147(1):21-35. doi: 10.1023/A:1009846507652

Gratani L. Plant phenotypic plasticity in response to environmental factors. Advances in Botany. 2014;117. doi: $10.1155 / 2014 / 208747$

Guisan A, Zimmermann NE. Predictive habitat distribution models in ecology. Ecological modelling. 2000;135(2-3):147-186. doi: 10.1016/S03043800(00)00354-9

Haddad NM, Brudvig LA, Clobert J, Davies KF, Gonzalez A, Holt RD, et al. Habitat fragmentation and its lasting impact on Earth's ecosystems. Science advances. 2015;1(2):e1500052. doi: 10.1126/ sciadv. 1500052

Instituto Estadual do Ambiente - INEA. Plano de Manejo do Parque Estadual da Serra da Tiririca. Governo do Estado do Rio de Janeiro. 2015 [cited: 19 July 2021]. Available from:

http://www.femerj.org/wp-content/uploads/Planode-manejo-do-Parque-Estadual-da-Serra-da-TiriricaPESET.pdf

Instituto Nacional de Pesquisas Espaciais - INPE. Portal do Monitoramento de Queimadas e Incêndios Florestais. 2021[cited: 18 July 2021]. Available from: ttp://www.inpe.br/queimadas

Kneip LM. A sequência cultural do sambaqui de Camboinhas, Itaipu-Niterói, Rio de Janeiro. Museu Nacional. 1995;3:3-12.

Laurance WF, Lovejoy TE, Vasconcelos HL, Bruna EM, Didham RK, Stouffer PC, et al. Ecosystem decay of Amazonian forest fragments: a 22-year investigation. Conservation biology. 2002;16(3):605618. doi: 10.1046/j.1523-1739.2002.01025.x

Laurance WF, Nascimento HE, Laurance SG, Andrade A, Ribeiro JE, Giraldo JP, et al. Rapid decay of tree-community composition in Amazonian forest fragments. Proceedings of the National Academy of Sciences. 2006a;103(50):19010-19014. doi: 10.1073/ pnas.0609048103

Laurance WF, Nascimento HE, Laurance SG, Andrade AC, Fearnside PM, Ribeiro JE, et al.
Rainforest fragmentation and the proliferation of successional trees. Ecology. 2006b;87(2):469-482. doi: 10.1890/05-0064

Laurance WF, Nascimento HE, Laurance SG, Andrade A, Ewers RM, Harms KE, et al. Habitat fragmentation, variable edge effects, and the landscape-divergence hypothesis. PLoS One. 2007;2(10):e1017. doi: 10.1371/journal. pone. 0001017

Laurance WF, Curran TJ. Impacts of wind disturbance on fragmented tropical forests: a review and synthesis. Austral Ecology. 2008;33(4):399-408. doi: $10.1111 / \mathrm{j} .1442-9993.2008 .01895 . x$

Laurance WF, Camargo JLC, Luizão RCC, Laurance SG, Pimm SL, Bruna EM, et al. The fate of Amazonian forest fragments: A 32-year investigation. Biological Conservation. 2011;144(1):56-67. doi: 10.1016/j.biocon.2010.09.021

Laurance WF, Camargo JL, Fearnside PM, Lovejoy TE, Williamson GB, Mesquita RC, et al. An Amazonian rainforest and its fragments as a laboratory of global change. Biological Reviews. 2018;93(1):223-247. doi: 10.1111/brv.12343

Magnago LFS, Edwards DP, Edwards FA, Magrach A, Martins SV, Laurance WF. Functional attributes change but functional richness is unchanged after fragmentation of Brazilian Atlantic forests. Journal of ecology. 2014;102(2):475-485. doi: 10.1111/13652745.12206

Magnago LFS, Rocha MF, Meyer L, Martins SV, Meira-Neto JAA. Microclimatic conditions at forest edges have significant impacts on vegetation structure in large Atlantic forest fragments. Biodiversity and Conservation. 2015;24(9):23052318. doi: 10.1007/s10531-015-0961-1

Magnago LFS, Magrach A, Barlow J, Schaefer CEGR, Laurance WF, Martins SV, et al. Do fragment size and edge effects predict carbon stocks in trees and lianas in tropical forests? Functional Ecology. 2017;31(2):542-552. doi: 10.1111/1365-2435.12752

Muller-Landau HC. Interspecific and inter-site variation in wood specific gravity of tropical trees. Biotropica. 2004;36(1), 20-32. doi: 10.1111/j.17447429.2004.tb00292.x

\section{Revista Árvore 2022;46:e4603}


Murcia C. Edge effects in fragmented forests: implications for conservation. Trends in Ecology \& Evolution. 1995;10(2):58-62. doi: 10.1016/S01695347(00)88977-6

Myers N, Mittermeier RA, Mittermeier CG, Da Fonseca GA, Kent J. Biodiversity hotspots for conservation priorities. Nature. 2000;403(6772):853858. doi: $10.1038 / 35002501$

Nascimento HE, Laurance WF. Efeitos de área e de borda sobre a estrutura florestal em fragmentos de floresta de terra-firme após 13-17 anos de isolamento. Acta Amazonica. 2006;36(2):183-192. doi: 10.1590/S0044-59672006000200008

Oliveira-Filho AT, Mello JM, Scolforo JRS. Effects of past disturbance and edges on tree community structure and dynamics within a fragment of tropical semideciduous forest in south-eastern Brazil over a five-year period (1987-1992). Plant Ecology. 1997;131(1):45-66. doi: 10.1023/A:1009744207641

Oliveira RR, Patzlaff RG, Scheel-Ybert R. A floresta como esconderijo: arqueologia da paisagem na mata atlântica do Rio de Janeiro. Revista Mosaico-Revista de História. 2020;13(2):61-82. doi: 10.18224/mos. v13i1.7984

Padilha DL, Marco-Júnior PD. A gap in the woods: Wood density knowledge as impediment to develop sustainable use in Atlantic Forest. Forest ecology and management. 2018;424:448-457. doi: 10.1016/j. foreco.2018.05.012

Pires JPDA, Silva AGD, Freitas L. Plant size, flowering synchrony and edge effects: What, how and where they affect the reproductive success of a Neotropical tree species. Austral Ecology. 2014;39(3):328-336. doi: 10.1111/aec.12082

Pontes DMF, Engel VL, Parrotta JA. Forest structure, wood standing stock, and tree biomass in different restoration systems in the Brazilian Atlantic Forest. Forests. 2019;10(7):588. doi: 10.3390/f10070588

Poorter L, McDonald I, Alarco A, Fichtler E, Licona $\mathrm{JC}$, Peña-Claros M, et al. The importance of wood traits and hydraulic conductance for the performance and life history strategies of 42 rainforest tree species. New Phytol. 2010;185:481-492. doi: 10.1111/j.1469-8137.2009.03092.x
Poorter L, Rozendaal DM, Bongers F, AlmeidaCortez JS, Zambrano AMA, Álvarez FS, et al. Wet and dry tropical forests show opposite successional pathways in wood density but converge over time. Nature Ecology \& evolution. 2019;3(6):928-934. doi: 10.1038/s41559-019-0882-6

R Core Team. A Language and Environment for Statistical Computing. Vienna: R Foundation for Statistical Computing; 2021.

Rezende CL, Scarano FR, Assad ED, Joly CA, Metzger JP, Strassburg BBN, et al. From hotspot to hopespot: an opportunity for the Brazilian Atlantic Forest. Perspectives in Ecology and Conservation. 2018;16(4):208-14. doi: 10.1016/j. pecon.2018.10.002

Rio de Janeiro. Lei Estadual n ${ }^{\circ} 1.901$, de 29 de novembro de 1991. Dispõe sobre a criação do Parque Estadual da Serra da Tiririca e dá outras providencias. 1991 [cited 19 July 2021]. Avaliable from: http://alerjln1.alerj.rj.gov.br/CONTLEI.NSF/ bff0b82192929c2303256bc30052cb1c/0a9eb985

Ripley B, Venables B, Bates DM, Hornik K, Gebhardt A, Firth D, et al. Package 'mass'. Cran r. 2013;538:113-120.

Rocha DSB, Amorim AMA. Heterogeneidade altitudinal na Floresta Atlântica setentrional: um estudo de caso no sul da Bahia, Brasil. Acta Botanica Brasilica. 2012;26(2):309-327. doi: 10.1590/S010233062012000200008

Rodrigues PJFP, Melo LR, Abreu RC, Iguatemy MA. Edge Effects of Oil Pipeline Canopy Openings on Tree Community Structure and Dynamics in a Montane Atlantic Forest. Journal of Geoscience and Environment Protection. 2016;4(7):132-140. doi: 10.4236/gep.2016.47014

Rüger N, Wirth C, Wright SJ, Condit R. Functional traits explain light and size response of growth rates in tropical tree species. Ecology. 2012;93(12):26262636. doi: 10.1890/12-0622.1

Salomão RP, Brienza-Júnior S, Rosa NA. Dinâmica de reflorestamento em áreas de restauração após mineração em unidade de conservação na Amazônia. Revista Árvore. 2014;38(1):1-24. doi: 10.1590/ S0100-67622014000100001

Santos BA, Peres CA, Oliveira MA, Grillo A,

\section{Revista Árvore 2022;46:e4603}


Alves-Costa CP, Tabarelli M. Drastic erosion in functional attributes of tree assemblages in Atlantic forest fragments of northeastern Brazil. Biological conservation. 2008;141(1):249-260. doi: 10.1016/j. biocon.2007.09.018

Santo-Silva EE, Almeida WR, Tabarelli M, Peres CA. Habitat fragmentation and the future structure of tree assemblages in a fragmented Atlantic forest landscape. Plant ecology. 2016;217(9):1129-1140. doi: $10.1007 / \mathrm{s} 11258-016-0638-1$

SOS Mata Atlântica, INPE. Relatório anual 2019. [cited: 19 July 2021]. Available from: https://www. sosma.org.br/sobre/relatorios-e-balancos/

Tabarelli M, Aguiar AV, Girao LC, Peres CA, Lopes AV. Effects of pioneer tree species hyperabundance on forest fragments in northeastern Brazil. Conservation Biology. 2010;24(6);1654-1663. doi: 10.1111/j.1523-1739.2010.01529.x

Turchetto F, Araujo MM, Callegaro RM, Griebeler AM, Mezzomo JC, Berghetti AL, et al. Phytosociology as a tool for forest restoration: a study case in the extreme South of Atlantic
Forest Biome. Biodiversity and Conservation. 2017;26(6):1463-1480. doi: 10.1007/s10531-017$1310-3$

Vallejo LR. Conflitos Territoriais em Parques Estaduais no Rio de Janeiro: uma avaliação à luz das políticas de governo. Revista geopaisagem. $2005 ; 4(7)$.

Violle C, Navas ML, Vile D, Kazakou E, Fortunel C, Hummel I, et al. Let the concept of trait be functional!. Oikos, 2007;116(5):882-892. doi: 10.1111/j.00301299.2007.15559.x

Wright TE, Kasel S, Tausz M, Bennett LT. Edge microclimate of temperate woodlands as affected by adjoining land use. Agricultural and Forest Meteorology. 2010;150(7-8):1138-1146. doi: 10.1016/j.agrformet.2010.04.016

Zimermann OL, Uller FH, Klitzke RA, Eleotério RJ, Vibrans AC. Towards the Fulfillment of a Knowledge Gap: Wood Densities for Species of the Subtropical Atlantic Forest. Data. 2019;4(3):104. doi: 10.3390/ data4030104 